\title{
CORPORATE RESTRUCTURING
}

\author{
ANIL OJHA (SMT. K.G.MITTAL INSTITUTE OF MANAGEMENT, I.T. AND RESEARCH ) \\ PHONE NO.9029770856 (Anilojha46@yahoo.com)
}

\section{SUMIT BAIRAGI (SMT. K.G.MITTAL INSTITUTE OF MANAGEMENT, I.T. AND RESEARCH) \\ PHONE NO. 08888341050 (Bairagisumit495@gmail.com)}

\begin{abstract}
Corporate Restructuring has become a major component in the financial and economic environment all over the world. It is the process of redesigning one or more aspects of a company. The process of reorganizing a company may be implemented due to a number of different factors, like positioning the company to be more competitive, survive a currently adverse economic climate, or poise the corporation to move in an entirely new direction and many more. Corporate restructuring is needed to counter challenges in competitive business environment. Most of the organizations carry out corporate restructuring as per the need of the business. Some do it through mergers, acquisitions, and some by demergers as well; while some others make structural changes and carry out resource optimization in the organization. This paper analyses the success rate of corporate restructuring programme in India. It also tries to understand the implication of corporate restructuring programme with the help of a case study. The present paper is mainly based on secondary data. The paper makes use of SPSS 16 and MS-excel for data Analysis
\end{abstract}

KEYWORDS: Corporate Restructuring, Challenges, Merger, Demerger. 


\section{INTRODUCTION}

Corporate restructuring is one of the most complex yet fundamental phenomena that management confronts. Each company has two opposite strategies from which to choose: either to diversify or refocus on its core business. While diversifying represents the expansion of corporate activities, refocus characterizes a concentration on its core business. From this perspective, corporate restructuring is reduction in diversification. Corporate restructuring is an episode exercise, not related to investment in new plant and machinery which involve a significant change in one or more of the following:

- Pattern of ownership and control

- Composition of liability

It is a comprehensive process by which a firm can consolidate its business operations and strengthen its position for achieving the desired objectives: (A) synergetic (B) competitive (C) successful. It involves significant reorientation, re-organisation or realignment of assets and liabilities of the organisation through conscious management action to improves future cash flow stream and make more profitable and efficient.

\section{$\underline{\text { Literature Review }}$}

Laura Horn (2012) have emphasized on the essentially political nature of corporate governance regulation and argues that the transformation of corporate governance regulation is part of a broader political project of economic restructuring and marketmaking in the EU and illustrated that how company law has become increasingly focused on the rights of shareholders, while worker rights have been relegated to the area of social policies and labour law. Desai; Klock; \& Mansi (2011) have examined the role played by the parent's motive in undertaking a carve-out and found that the post-IPO parent ownership significantly affects the acquisition likelihood and the level of acquisition premium. Zahid \& Shah (2011) have stated that businesses from developing countries have started to buy out businesses of developed countries as their economies are doing better compared to the developed world due to low cost of production. Indian and Chinese businessmen are the most aggressive compared to rest in this regard. Owolabi \& Dada (2011) has examined the role, nature, composition, objectives and functions of an effective audit committee in achieving reliable corporate governance and suggested that the recent business and governance failures demonstrated that a great step in corporate governance restructuring is a must.

\section{OBJECTIVES}

- To determine the success rate of corporate restructuring programme

- To ascertain the implications of corporate restructuring programme 


\section{RESEARCH METHODOLOGY}

The sample size comprises of 9 major companies which went through the process of corporate restructuring during the period 2000-2010. The sample composition is as follows:

1. Hindustan unilever

2. MahindraSatyam

3. Wokhardt

4. ITC(

5. GSK(GlaxoSmithKline)
6. Shri Asthavinayak Cine Vision

7. Arvind Mills

8. Crompton Greaves

9. Voltas

Mean, standard deviation and ' $t$ ' test have been used as tools of analysis for evaluating the financial performance of firms. The paper makes use of SPSS 16 and MS-excel for data Analysis. 


\section{DATA ANALYSIS}

\section{A. Success Rates}

$\mathbf{H}_{(\mathbf{0})}$ 1: There is no significant difference in pre and post profitability margins in companies which went for restructuring for the selected period
$\mathbf{H}_{(\mathbf{1})}$ 1: There is a significant difference in pre and post profitability margins in companies which went for restructuring for the selected period

Table (1): Paired Samples Statistics

\begin{tabular}{|cl|c|c|c|c|}
\hline & & Mean & $\mathrm{N}$ & $\begin{array}{c}\text { Std. } \\
\text { Deviation }\end{array}$ & $\begin{array}{c}\text { Std. Error } \\
\text { Mean }\end{array}$ \\
\hline Pair 1 & Pre_year3 & 9.6244 & 9 & 9.20107 & 3.06702 \\
& Post_year1 & 12.9644 & 9 & 7.83658 & 2.61219 \\
\hline
\end{tabular}

Data Interpretation: Table (1) shows the descriptive statistics of the corporate restructuring process for the nine companies and the profitability margins are taken for the immediate years of corporate restructuring i.e. immediate preceding year and immediate consecutive year (Pre year 3\& Post year $1)$. Thus the mean profitability scores for Pre year $3 \&$ Post year 1 is $9.6 \& 12.9$ respectively which indicates a high difference due to thecorporate restructuring process.

Table (2): Paired Samples Correlations

\begin{tabular}{|ll|c|c|c|}
\hline & $\mathrm{N}$ & Correlation & Sig. \\
\hline Pair 1 & $\begin{array}{l}\text { Pre_year3 \& } \\
\text { Post_year1 }\end{array}$ & 9 & .859 & .003 \\
\hline
\end{tabular}

Data Interpretation: Table (2) describes about the correlations between the variables and it has been found that the R stands at 0.859 at $90 \%$ confidence levels and is highly significant since the $\mathrm{p}$ value is 0.003 is quite lesser than 0.1 . Thus there is very strong correlation between the pair.

Table (3): Paired Samples Test

\begin{tabular}{|c|c|c|c|c|c|c|c|c|}
\hline \multirow{3}{*}{ 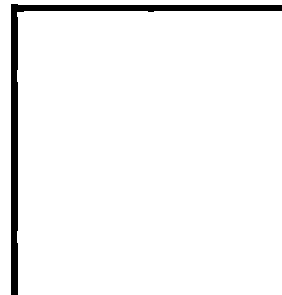 } & \multicolumn{5}{|c|}{ Paired Differences } & \multirow[b]{3}{*}{$\mathrm{t}$} & \multirow[b]{3}{*}{$\mathrm{df}$} & \multirow{3}{*}{$\begin{array}{l}\text { Sig. (2) } \\
\text { tailed) }\end{array}$} \\
\hline & \multirow[b]{2}{*}{ Mean } & \multirow[b]{2}{*}{ Std. Dev. } & \multirow[b]{2}{*}{ S.E Mean } & \multicolumn{2}{|c|}{$\begin{array}{l}95 \% \text { Confidence } \\
\text { Interval of the } \\
\text { Difference }\end{array}$} & & & \\
\hline & & & & Lower & Upper & & & \\
\hline
\end{tabular}


Table (3): Paired Samples Test

\begin{tabular}{|c|c|c|c|c|c|c|c|c|}
\hline & \multicolumn{5}{|c|}{ Paired Differences } & \multirow[b]{3}{*}{$\mathrm{t}$} & \multirow[b]{3}{*}{ df } & \multirow{3}{*}{$\begin{array}{l}\text { Sig. (2 } \\
\text { tailed) }\end{array}$} \\
\hline & \multirow[b]{2}{*}{ Mean } & \multirow[b]{2}{*}{ Std. Dev. } & \multirow[b]{2}{*}{ S.E Mean } & \multicolumn{2}{|c|}{$\begin{array}{l}95 \% \text { Confidence } \\
\text { Interval of the } \\
\text { Difference }\end{array}$} & & & \\
\hline & & & & Lower & Upper & & & \\
\hline $\begin{array}{c}\text { Pair } 1 \text { Pre_yea } \\
\text { r3 - } \\
\text { Post_ye } \\
\text { ar1 }\end{array}$ & -3.34000 & 4.70710 & 1.56903 & -6.95820 & .27820 & -2.129 & 8 & .066 \\
\hline
\end{tabular}

Data Interpretation: Table (3) is very important since it actually states that whether corporate restructuring process has made any difference on profitability of the selected firms for the above period. Further analysis of the data reveals that the $\mathrm{T}$ statistics is -2.129 with significant level of 0.066 which is quite lesser than 0.1 at $90 \%$ confidence levels. Thus it can be concluded that definitely the corporate restructuring process has

$\mathbf{H}_{(0)}$ 2: There is no significant difference in pre and post profitability margins in companies which went for restructuring for pre and post first years brought significant difference in the profitability margins of selected companies. It was further analysed that the change brought by the process was quite positive and it increased the profitability margins for most of the companies. Therefore we reject null hypotheses and accept alternative hypotheses that there is a significant difference in pre and post profitability margins in companies which went for restructuring for the selected period.

$\mathbf{H}_{(\mathbf{1})}$ 2: There is no significant difference in pre and post profitability margins in companies which went for restructuring for pre and post first years

Table (4): Paired Samples Statistics

\begin{tabular}{|c|c|c|c|c|c|}
\hline & & Mean & $\mathrm{N}$ & $\begin{array}{c}\text { Std. } \\
\text { Deviation } \\
\end{array}$ & $\begin{array}{l}\text { Std. } \\
\text { Error } \\
\text { Mean } \\
\end{array}$ \\
\hline Pair 1 & $\begin{array}{l}\text { Pre_yea } \\
\text { r1 } \\
\text { Post_ye } \\
\text { ar1 }\end{array}$ & $\begin{array}{r}-83.0533 \\
12.9644\end{array}$ & 9 & $\begin{array}{r}278.36795 \\
7.83658\end{array}$ & $\begin{array}{r}92.7893 \\
2 \\
2.61219\end{array}$ \\
\hline
\end{tabular}


Table (5):Paired Samples Correlations

\begin{tabular}{|ll|l|l|l|}
\hline & & $\mathrm{N}$ & $\begin{array}{c}\text { Correlatio } \\
\mathrm{n}\end{array}$ & \multicolumn{1}{c|}{ Sig. } \\
\hline Pair 1 & $\begin{array}{l}\text { Pre_year1 \& } \\
\text { Post_year1 }\end{array}$ & 9 & -.033 & .934 \\
\hline
\end{tabular}

Table (6):Paired Samples Test

\begin{tabular}{|c|c|c|c|c|c|c|c|c|c|}
\hline & & \multirow[b]{3}{*}{ Mean } & \multicolumn{4}{|c|}{ Paired Differences } & \multirow[b]{3}{*}{$\mathrm{t}$} & \multirow{3}{*}{$\begin{array}{l}\mathrm{d} \\
\mathrm{f}\end{array}$} & \multirow[b]{3}{*}{ Sig. (2-tailed) } \\
\hline & & & \multirow{2}{*}{$\begin{array}{l}\text { Std. } \\
\text { Devia } \\
\text { tion }\end{array}$} & \multirow{2}{*}{$\begin{array}{l}\text { Std. } \\
\text { Error } \\
\text { Mean } \\
\end{array}$} & \multicolumn{2}{|c|}{$\begin{array}{c}95 \% \text { Confidence } \\
\text { Interval of the } \\
\text { Difference }\end{array}$} & & & \\
\hline & & & & & Lower & Upper & & & \\
\hline Pair 1 & $\begin{array}{l}\text { Pre_y } \\
\text { ear1_- } \\
\text { Post_- } \\
\text { year1 }\end{array}$ & $\begin{array}{l}- \\
96.01 \\
778\end{array}$ & $\begin{array}{l}278.7 \\
3274\end{array}$ & $\begin{array}{l}92.910 \\
91\end{array}$ & -310.2707 & 118.2351 & -1.033 & 8 & .332 \\
\hline
\end{tabular}

Data Interpretation: Table (6) is very important since it actually states that whether corporate restructuring process has made any difference on profitability of the selected firms for the above period. Further analysis of the data reveals that the $\mathrm{T}$ statistics is -1.033 with significant level of 0.322 which is quite higher than 0.05 at $95 \%$ confidence levels. Thus it can be concluded that the

$\mathbf{H}_{(\mathbf{0})}$ 3: There is no significant difference in pre and post profitability margins in companies which went for restructuring for pre and post second years corporate restructuring process has not brought any significant difference in the profitability margins of selected companies. Therefore we accept null hypotheses that there is no significant difference in pre and post profitability margins in companies which went for restructuring for pre and post first years
$\mathbf{H}_{(\mathbf{1})}$ 3: There is significant difference in pre and post profitability margins in companies which went for restructuring for pre and post second years 
Table (7): Paired Samples Statistics

\begin{tabular}{|cc|c|c|c|c|}
\hline & & Mean & N & $\begin{array}{c}\text { Std. } \\
\text { Deviation }\end{array}$ & $\begin{array}{c}\text { Std. } \\
\text { Error } \\
\text { Mean }\end{array}$ \\
\hline Pair 1 & $\begin{array}{c}\text { Pre_yea } \\
\text { r2 } \\
\text { Post_ye } \\
\text { ar2 }\end{array}$ & 9.1056 & 9 & 8.71151 & 2.90384 \\
& 13.7222 & 9 & 7.53074 & 2.51025 \\
\hline
\end{tabular}

Data Interpretation: Table (7) shows the descriptive statistics of the corporate restructuring process for the nine companies and the profitability margins are taken for the immediate years of corporate restructuring i.e. immediate preceding year and immediate consecutive year (Pre year $2 \&$ Post year 2 ). Thus the mean profitability scores for Pre year $2 \&$ Post year 2 is $9.1 \& 13.7$ respectively which indicates a high difference due to thecorporate restructuring process.

\section{Table (8): Paired Samples Correlations}

\begin{tabular}{|lc|c|c|c|}
\hline & & N & $\begin{array}{c}\text { Correlatio } \\
\text { n }\end{array}$ & Sig. \\
\hline Pair 1 & $\begin{array}{c}\text { Pre_year2 \& } \\
\text { Post_year2 }\end{array}$ & 9 & .775 & .014 \\
\hline
\end{tabular}

Data Interpretation: Table (8) describes about the correlations between the variables and it has been found that the $\mathrm{R}$ stands at 0.775 at $95 \%$ confidence levels and is highly significant since the $\mathrm{p}$ value is 0.014 is quite lesser than 0.05 .
Thus there is very strong correlation between the pair. 
Table (9): Paired Samples Test

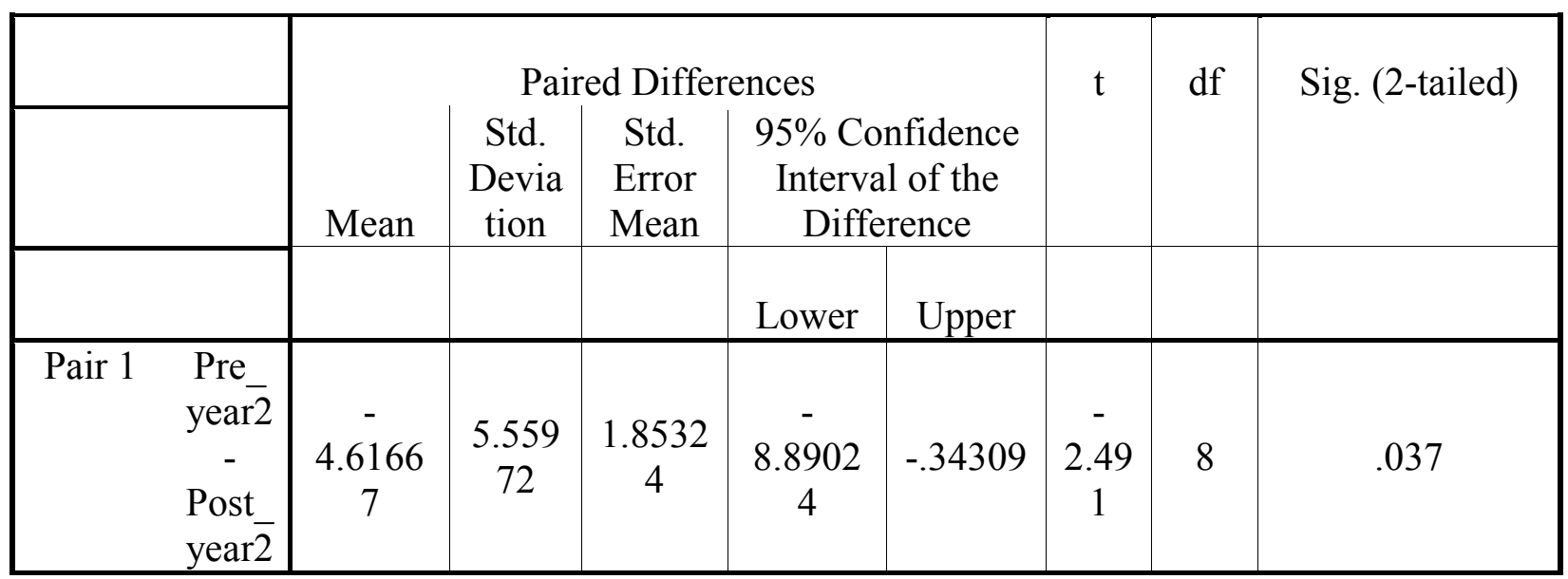

Data Interpretation: Table (9) is very important since it actually states that whether corporate restructuring process has made any difference on profitability of the selected firms for the above period. Further analysis of the data reveals that the $T$ statistics is -2.491 with significant level of 0.037 which is quite lesser than 0.05 at $95 \%$ confidence levels. Thus it can be concluded that definitely the corporate restructuring process has brought significant

$\mathbf{H}_{(0)} \mathbf{4}$ :There is no significant difference in pre and post profitability margins in companies which went for restructuring for pre and post third years difference in the profitability margins of selected companies. It was further analysed that the change brought by the process was quite positive and it increased the profitability margins for most of the companies. Therefore we reject null hypotheses and accept alternative hypotheses that there is significant difference in pre and post profitability margins in companies which went for restructuring for pre and post second years

$\mathbf{H}_{(1)}$ 4:There is significant difference in pre and post profitability margins in companies which went for restructuring for pre and post third year

Table (10): Paired Samples Statistics

\begin{tabular}{|cc|c|c|c|c|}
\hline & & Mean & N & $\begin{array}{c}\text { Std. } \\
\text { Deviation }\end{array}$ & $\begin{array}{c}\text { Std. } \\
\text { Error } \\
\text { Mean }\end{array}$ \\
\hline Pair 1 & $\begin{array}{c}\text { Pre_yea } \\
\text { r3 } \\
\text { Post_ye } \\
\text { ar3 }\end{array}$ & 9.6244 & 9 & 9.20107 & 3.06702 \\
& 13.5544 & 9 & 9.05731 & 3.01910 \\
\hline
\end{tabular}


Data Interpretation: Table (10) shows the descriptive statistics of the corporate restructuring process for the nine companies and the profitability margins are taken for the immediate years of corporate restructuring i.e. immediate preceding year and immediate consecutive year (Pre year 3 \& Post year 3 ). Thus the mean profitability scores for Pre year $3 \&$ Post year 3 is $9.6 \& 13.5$ respectively which indicates a high difference due to thecorporate restructuring process.

Table (11): Paired Samples Correlations

\begin{tabular}{|ll|l|l|l|}
\hline & & $\mathrm{N}$ & $\begin{array}{c}\text { Correlatio } \\
\mathrm{n}\end{array}$ & \multicolumn{1}{c|}{ Sig. } \\
\hline Pair 1 & $\begin{array}{l}\text { Pre_year3 \& } \\
\text { Post_year3 }\end{array}$ & 9 & .860 & .003 \\
\hline & & & \\
\hline
\end{tabular}

Data Interpretation: Table (11) describes about the correlations between the variables and it has been found that the $\mathrm{R}$ stands at 0.860 at $95 \%$ confidence levels and is highly significant since the $\mathrm{p}$ value is 0.003 is quite lesser than 0.05 . Thus there is very strong correlation between the pair.

Table (12): Paired Samples Test

\begin{tabular}{|c|c|c|c|c|c|c|c|c|c|}
\hline & \multicolumn{5}{|c|}{ Paired Differences } & \multirow[b]{3}{*}{$\mathrm{t}$} & \multirow{3}{*}{$\begin{array}{l}d \\
f\end{array}$} & \multirow{3}{*}{$\begin{array}{l}\text { Sig. (2- } \\
\text { tailed) }\end{array}$} \\
\hline & & \multirow{2}{*}{ Mean } & \multirow{2}{*}{$\begin{array}{c}\text { Std. } \\
\text { Deviation } \\
\end{array}$} & \multirow{2}{*}{$\begin{array}{l}\text { Std. } \\
\text { Error } \\
\text { Mean }\end{array}$} & \multicolumn{2}{|c|}{$\begin{array}{c}95 \% \\
\text { Confidence } \\
\text { Interval of the } \\
\text { Difference }\end{array}$} & & & \\
\hline & & & & & Lower & Upper & & & \\
\hline Pair 1 & $\begin{array}{l}\text { Pre_ye } \\
\text { ar3- } \\
\text { Post_y } \\
\text { ear3 }\end{array}$ & $\begin{array}{l}- \\
3.9300 \\
0\end{array}$ & 4.82886 & $\begin{array}{l}1.6096 \\
2\end{array}$ & $\begin{array}{l}- \\
7.6417 \\
9\end{array}$ & $\begin{array}{l}- \\
.21821\end{array}$ & $\overline{2} .442$ & 8 & .040 \\
\hline
\end{tabular}

Data Interpretation: Table (12) is very important since it actually states that whether corporate restructuring process has made any difference on profitability of the selected firms for the above period. Further analysis of the data reveals that the $T$ statistics is -2.442 with significant level of 0.040 which is quite lesser than 0.05 at $95 \%$ confidence levels. Thus it can be concluded that definitely the corporate restructuring process has brought significant difference in the profitability margins of selected companies. It was further 
analysed that the change brought by the increased the profitability margins for most of the companies. Therefore we reject null hypotheses and accept alternative hypotheses that there is

\section{B. CASE STUDY}

\section{CORPORATE RESTRUCTURING AT ARVIND MILLS}

The case provides an overview of the Arvind Mills' expansion strategy, which resulted in the company's poor financial health in the late 1990s. In the mid 1990s, Arvind Mills' undertook a massive expansion of its denim capacity in spite of the fact that other cotton fabrics were slowly replacing the demand for denim. The expansion plan was funded by loans from both Indian and overseas financial institutions. With the demand for denim slowing down, Arvind Mills found it difficult to repay the loans, and thus the interest burden on the loans shot up. In the late 1990s, Arvind Mills ran into deep financial problems because of its debt burden. As a result, it incurred huge losses in the late 1990s. The case also discusses in detail the Arvind Mills debtrestructuring plan for the long-term debts being taken up in February 2001.

\section{ISSUES:}

Debt driven expansion plan, financial restructuring of Arvind Mills

\section{KEYCONCERN:}

Global recession will dampen the demands.

$>$ Depends highly on the movement of cotton and denim price. process was quite positive and it significant difference in pre and post profitability margins in companies which went for restructuring for pre and post third years.

\section{Introduction.}

In the early 1990s, Arvind Mills initiated massive expansion of its denim capacity.By the late 1990s, Arvind Mills was the third largest manufacturer of denim in the world, with a capacity of 120 million meters.

However, in the late 1990s, due to global as well as domestic overcapacity in denim and the shift in fashion to gabardine and corduroy, denim prices crashed and Arvind Mills was hit hard. The expansion had been financed mostly by loans from domestic and overseas institutional lenders.

As the denim business continued to decline in the late 1990s and early 2000, Arvind Mills defaulted on interest payments on every loan, debt burden kept on increasing.

In 2000, the company had a total debt of Rs 27 billion, of which 9.29 billion was owed to overseas lenders.

In 2000, Arvind Mills, once the darling of the bourses was in deep trouble. Its share price was hovering between a 52 week high of Rs 20 and low of Rs 9 (in the mid 1990s, the share price was closer to Rs 150). Leading financial analysts no longer tracked the Arvind Mills scrip.

The company's credit rating had also come down. CRISIL downgraded it to "default" in October 2000 from "highest safety" in 1997. In early 2001, Arvind Mills announced a restructuring proposal to improve its financial health and reduce its debt burden. 
The proposal was born out of several meetings and negotiations between the company and a steering committee of lenders. As a result of the restructuring plan the interest burden came down substantially and got Arvind Mills the distinction of becoming the first Indian corporate to restructure its entire debt in a single go. Also, post restructuring, Arvind has reported a profit of Rs. 10 crore for the first quarter of the financial year 2002, after a gap of three years. The sheer instinct of Sanjay to survive in the business coupled with some bold and frank decisions had enabled Arvind Mills to come out of its problems and stand again on its feet.

\section{Findings:}

1. By late 1990s, Arvind Mills was in deep financial trouble because of its increasing debt and interest burden.

2. Its total long-term debt was estimated at Rs 27 billion, out of which the total overseas debt was Rs 9.29 billion and debt to Indian institutional lenders was Rs 17.71 billion.

3. Arvind Mills had defaulted on interest payments on every loan.

4. ICICI was the largest Indian institutional lender, with a loan of over Rs 5 billion to Arvind Mills. In 2000, the company reported a net loss of Rs 3.16 billion against a profit of Rs .14 billion in 1999.

\section{Solutions}

1. In February 2001, Arvind Mills announced a debt restructuring
2. plan for its long term debt. While the company set itself a minimum debt buyback target of Rs 5.5 billion, the management was hopeful of a larger amount, possibly Rs 7.5 billion.

3. In mid-2001, Arvind Mills got the approval of a majority of the lenders for its debt restructuring scheme. Forty-three out of fiftyfour lenders approved the plan..

4. Some of the banks agreed to the buyback at a $55 \%$ discount on the principal amount, while some agreed to a five year rollover for which they would be entitled to interest plus the principal. Some banks also agreed to a ten year rollover for which they would be paid a higher rate of interest plus principal. The debt revamp was expected to reduce Arvind Mills' interest burden by $50 \%$.

\section{Arvind Mills board Debts restructuring plan:}

Company has drawn major restructuring plan, which involves:

1. Entry into industrial or performance fabric.

2. Focus on growing the existing brands and retail vertical.

3. Unlocking value from the real estate.

4. De-leveraging of the balance sheet.

5. Outsourcing of non-core activity. 


\section{FINDING OF RESEARCH}

- Most of the company's profitability margins are affected after corporate restructuring.

- Companies mostly increase their profitability margin after their corporate restructuring.

\section{CONCLUSION}

The corporate restructuring helps the firms to in a positive way by way of increasing their profitability margin

\section{References}

$>$ Chintal A. Desai; Mark S. Klock; Sattar A. Mansi (2011), "On the Acquisition of Equity carveouts", Journal of Banking \& Finance, Vol.: 35, No.: 12, December 2011, pp 3432-3449

$>$ Laura Horn (2012),“Corporate Governance in Crisis? The Politics of EU Corporate Governance Regulation", European Law Journal, Vol.18, No. 1, Jan 2012, pp 83-107

$>$ Nauman Zahid; Asif Mujtaba Shah (2011), "Mergers and Acquisitions in International Business", European Scientific Journal, Vol.: 22, August 2011, pp 43

$>$ Owolabi; S. A. ; Dada; S. O (2011)," Audit Committee: an Instrument of Effective Corporate Governance", European Journal of Economics, Finance and Administrative Sciences, No.: 35, August 2011, pp 173-183 